\title{
THE PROBLEM OF PROTECTION OF NATIONAL CONSTITUTIONAL IDENTITY IN INTEGRATION PROCESSES
}

\author{
Alina Pkhrikyan \\ Faculty of History and Law, Armenian State Pedagogical University
}

\begin{abstract}
The problem of protecting the constitutional identity, in contents of modern constitutional developments, becomes a top discussed topic by lawyers. We share the opinion of scholars that the constitutional identity is the manifestation of the national and political identity of the society, which is reflected in the content of the Constitution. Having a millennium history, including a rich legal history, Armenia is probably one of the states that, according to geopolitical situations and historical circumstances has very often had to defend its national, including constitutional identity. The report presents specific historical examples. Nowadays Armenia is actively integrating into globalization processes: on the one hand we join the Eurasian Economic Union, on the other hand, conclude a Comprehensive and Enhanced Partnership Agreement with the EU. These circumstances are new challenges for our country. The report also highlights the importance of the role of the Constitutional Court of the Republic of Armenia in maintaining the constitutional identity and in legal protection of national constitutional values.
\end{abstract}

Key words: constitutional identity, national identity, national constitutional values, the role of the Constitutional Court, integration process.

\section{INTRODUCTION}

As a result of modern globalization processes, the issue of maintaining national and, especially, the constitutional identity, has been discussed by different social-humanitarian sciences in various formats. The problem of protecting the constitutional identity, in the context of modern constitutional developments, becomes a top discussed topic by lawyers. And the problem is that the term „,constitutional identity" has different interpretations in the modern legal literature.

We share the opinion of scholars that the constitutional identity is the manifestation of the national and political identity of the society, which is completely reflected in the content of the Constitution ${ }^{1}$. Whether the Constitution works and how it works depends on the national, religious and cultural identity of those who are affected by the constitution. We also agree with the opinion of former President of the Constitutional Court of the Republic of Armenia prof. G. Harutyunyan according to which the person's constitutional identity is characterized by the integrity of the values and civil qualities by which he determines his place and role in constitutional relations as a direct bearer of constitutional values. ${ }^{2}$

1 SAJO, A., UITZ, R. The constitution of freedom an introduction to legal constitutionalism. Oxford university press, 2017, pp. $63-67$.

2 HARUTYUNYAN, G. The epistemological and axiological characteristics of constitutional identity of a human being. Available at http://concourt.am/armenian/structure/president/articles/article-january2018.pdf. 


\section{THE PROBLEM OF PRESERVING CONSTITUTIONAL IDENTITY IN A HISTORICAL RETROSPECTIVE}

Exploring the constitutions of different countries, we can see how the constitution can reflect specific features and accents of national identity in each specific society at a certain stage of its development. The constitutional law of foreign countries is a unique source of information about the problems in the field of national identity faced by each state.

Of course, each country has its unique history. Having an age-old history, including rich legal history, Armenia is probably one of the states that, according to geopolitical situations and historical circumstances has very often had to defend its national, as well as constitutional identity.

Armenia faced the problem of protecting its constitutional identity, in the modern sense of that term in the period of Soviet Union, where as you know the central authority attempted to eliminate all kinds of differences between member republics: national, religion, linguistic, cultural, legal and so on.

But we are proud to be the representative of one of the few nations, which in Soviet reality struggled as much as it was possible and preserved some elements of their national constitutional identity at the constitutional level.

One of those elements was the national language. The Constitution of the ASSR of 1937 and further Constitutions fixed the principle of the national language of judicial proceedings "Judicial proceedings in Soviet Armenia are conducted in Armenian language, in regions with Russian and Azerbaijanian habitants respectively in Russian or Azeri".

Special attention should be paid to the phenomenon of religious identity, which is protected at the constitutional level as an element of constitutional identity.

If we consider the history of legislative amendments to the constitutional law of the European countries, we can reveal that the religious motive is gradually being excluded out of the legislation. It is obvious that the positions of religious identity in the West are losing significance. Among the existing European constitutions with a strong religious component, can be mentioned the constitutions of Greece and Armenia.

Notwithstanding that Armenia is a secular State and according to Article 17 of the Constitution which establishes: "1. The freedom of activities of religious organizations shall be guaranteed in the Republic of Armenia. 2. Religious organizations shall be separate from the State".

Article 18 of the Constitution of Armenia establishes: "Article 18. The Armenian Apostolic Holy Church

1. The Republic of Armenia shall recognize the exclusive mission of the Armenian Apostolic Holy Church, as a national church, in the spiritual life of the Armenian people, in the development of their national culture and preservation of their national identity.2. The relations between the Republic of Armenia and the Armenian Apostolic Holy Church may be regulated by law".

In spite of the fact, that Armenia is a secular state and there are a number of religious organizations in it, such constitutional regulation is understandable, because Armenia, being the first state that adopted Christianity as a state religion in $301 \mathrm{AD}$, has a strict Christian heritage, which has its strong impact on the national constitutional identity. 


\section{ROLE OF THE CONSTITUTIONAL COURT IN PRESERVING CONSTITUTIONAL IDENTITY}

Nowadays a huge role in preserving constitutional identity and developing national constitutional law is delegated to the Constitutional Courts.

The judicial practice of the constitutional and supreme courts of many states, such as Germany, France, India, etc. uses the concept of constitutional identity as one of the methods of legal cognition in constitutional legal proceedings, particularly as a method of limitation in the implementation of international treaties. The same tendencies are observed in the practice of the Constitutional Court of the Republic of Armenia.

According to our Constitution, the Constitutional Court of the RA assumes a very important function: to ensure the supremacy of the Constitution. We attached great importance to the implementation of this function, especially when it comes to determining the issue whether accession to the international or integration organizations is in conformity with the Constitution.

As regards the integration processes in the modern world, it should be noted that Armenia is participating in both European and Eurasian integration processes, which undoubtedly have their impact on the development of the constitutional law of Armenia.

In this process, as was already mentioned, the Constitutional Court has a great role in maintaining the constitutional identity.

The issue is that for participating in any international organization it is necessary to sign an agreement or treaty. According to our Constitution the international treaties shall come into force only after being ratified or approved. Armenian Constitution and legislation stipulate that international treaty can be ratified only after being subject of preventive (preliminary) constitutional control by the Constitutional Court. Thus, the role of the Constitutional Court in preserving the Constitution and national constitutional values is very important.

While speaking about European integration it should be noted that on January 25, 2001 Armenia became a full member of the Council of Europe and, in accordance with Article 13 of the Parliamentary Assembly Opinion No. 221(2000) ${ }^{3}$, has undertaken the number of commitments upon its accession to the Council of Europe. The first of them was to sign the European Convention on Human Rights (ECHR).

At that time there was a situation when not all Conventional rights and freedoms were prescribed in the text of Constitution of 1995 edition. Taking into account this fact the Constitution Court declared that: "The fact is, that part of the rights and fundamental freedoms set out in the Convention and its Protocols are in conformity with the human rights and freedoms stipulated in the Constitution, and others are stipulated in the Constitution with other editions and formulations, and the rest of the rights stipulated in the Convention and its Protocols are not directly envisaged by the RA Constitution"

Our Constitutional Court resolved this constitutional problem on the basis of the fact that the constitution is a living organism, and the perceptions of fundamental rights can and should develop over time.

3 http://assembly.coe.int/nw/xml/XRef/Xref-XML2HTML-en.asp?fileid=16815\&lang=en.

4 Full text see: http://concourt.am/armenian/decisions/common/2002/sdv-350.htmd. 
So the Constitutional Court declared: "But taking into account that the rights and freedoms set forth in the Constitution are not exhaustive and shall not be construed to exclude other universally accepted human and civil rights and freedoms. And, based on the fact that the Constitutional norms on human rights and freedoms are not prohibitive, but authoritative, the Constitutional Court can declare that the Convention and the Protocols are in conformity with the norms and principles fixed in the RA Constitution".

With this decision, the Court, on the one hand, made it possible to ratify the European Convention; on the other hand, it launched new constitutional developments which resulted in the Constitutional Reforms in 2005.

Another integration process in which the decision of the Constitutional Court played an important role, especially in terms of protecting the fundamental constitutional principles is the issue of Accession to the Eurasian Economic Union.

On November 14, 2014 the Constitutional Court examined the Case on conformity of the obligations stipulated in the Treaty on "The accession to the Treaty of May 29, 2014 on "The Eurasian Economic Union" signed by the Republic of Armenia” signed on October 10, 2014 in Minsk with the Constitution of the Republic of Armenia ${ }^{5}$.

In this case the Constitutional Court faced some provisions of the Treaty which stipulated that a number of acts adopted by the Eurasian Union Institutions shall have direct application to some legal relations in the field of economy within the territory of Union.

Meanwhile according to our Constitutional (2005 edition) requirements numerous issues shall be prescribed exclusively by the laws of the Republic of Armenia, among which are:

1) terms and procedures for the exercise and protection of the rights by natural persons and legal entities;

2) restrictions on the rights and freedoms of natural persons and legal entities, their obligations, as well as forms, extent and procedure for liability thereof, means of compulsion and the procedure for such, types, amounts and procedures for the payment of taxes, duties and other binding fees paid by natural persons and legal entities;

3) cases, terms and procedures for control and oversight over the activities of legal entities and natural persons engaged in entrepreneurship (including checks, examinations and inspections); etc.

In its decision Constitutional Court declared that when the decision of the Institution of International organization does not conform to the current internal legislation or there is a lack of such kind of legal regulations, the decision of that kind of institutions are not applicable unless appropriate legislation is adopted.

This is a unique decision within the Eurasian Union because other Member States admit that the decisions of Eurasian Union Institutions can have direct application on legal relations arising within their territory.

This decision was grounded by the Court as follows: ...there are precise constitutional requirements, stemming from both axiology and a number of specific provisions of the RA Constitution. These are: 1) guaranteeing state and national sovereignty; 2) equality and mutual benefit of international relations; 3 ) provision of such possible restrictions on human rights, which are equivalent to the norms and principles of international law; 4) possibility for the actions of Armenia regarding

5 Full text see: http://concourt.am/armenian/decisions/common/2014/pdf/sdv-1175.pdf. 
the decisions of supranational bodies only within the framework of the Constitution of the Republic of Armenia. The Constitutional Court of the Republic of Armenia considers that any decision that does not comply with these requirements, adopted by any supranational body, to which the Republic of Armenia is a party, is not applicable in the Republic of Armenia."

In another case the Constitutional Court also opposed to the customary principles of economic unions in order to protect the Armenian Constitutional order and principles thereof.

In its decision on conformity of the obligations stipulated by the Treaty on the Customs Code of the Eurasian Economic Union signed on April 11, 2017 with the Constitution of the Republic of Armenia ${ }^{6}$, the Court declared that: "Having examined the nature of the international treaty in dispute as a legal act, the Constitutional Court of the Republic of Armenia states that this act, in fact, is considered to be ranked to the sources of supranational law. In the classical sense, the difference between international law and supranational law is mainly that the norms of the latter regulate not only the relations between states (horizontal), but also the relations operating within the state (vertical). The international practice of constitutional justice shows that the implementation of the preliminary constitutional control over the legislative acts, regulating vertical legal relations, which are the source of supranational law, cannot objectively guarantee the observance of the constitutional requirements for ensuring the mechanisms and procedures necessary for the direct action of the fundamental rights and freedoms of a person, proportionality and certainty of their limitations, as well as the effective implementation of these rights and freedoms".

On the basis of the above-mentioned, the Constitutional Court of the Republic of Armenia considers that the provisions of law that are the source of supranational law, corresponding to the content of the category "law” and regulating, the vertical legal relations may be a subject to constitutional review in the Constitutional Court in the procedure of „further constitutional control”, taking into account also the interpretation provided in the law enforcement practice to any position prescribed in them.

As we can see this approach is different from the practice of other supranational organizations such as EU.

\section{CONCLUSION}

The study of aforementioned cases enables to conclude that the Constitutional Court of the Republic of Armenia very frequently uses the concept of constitutional identity as a method of limiting the impact of supranational law provisions on the internal constitutional order. In our opinion, this practice derives from the lessons taught by our history.

\section{Bibliography:}

SAJO, A., UITZ, R. The constitution of freedom an introduction to legal constitutionalism. Oxford university press. 2017, pp. $63-67$.

HARUTYUNYAN, G. The epistemological and axiological characteristics of constitutional identity of a human being. [online]. Available at http://concourt.am/armenian/structure/president/articles/article-january2018.pdf.

6 Full text see: http://concourt.am/armenian/decisions/common/2017/pdf/sdv-1381.pdf. 
Decision SDV-350 of the Constitutional Court of RA

Decision SDV-1175 of the Constitutional Court of RA

Decision SDV-1381 of the Constitutional Court of RA

Parliamentary Assembly Council of Europe Opinion No. 221(2000)

\section{Contact information:}

Associate professor Alina Pkhrikyan, PhD.

alinapkhrikyan18@aspu.am,pkhrikyan@yahoo.com

Armenian State Pedagogical University

Faculty of History and Law

17 Tigran Mets ave. 0010

Yerevan

Armenia 